This Journal is available in Telkom University online Journals

Jurnal Manajemen Indonesia

\title{
Comprehending Leadership Patterns with focus on Servant Leadership
}

\author{
Dr. Manodip Ray Chaudhuri ${ }^{1}$, Sarina Pradhan ${ }^{2}$ \\ ${ }^{1,2}$ Xavier Business School, St. Xavier's University, Kolkata, India
}

\begin{abstract}
Leadership is the art of motivating a group of people to act towards achieving a specific goal. Leadership style is the method and approach of providing direction, implementing plans and motivating people. It is the sum total of explicit and implicit actions performed by the leader. The study investigates the different leadership styles in the organisation and a country wise classification of how leadership style varies across different nations. This is on the basis of factors like power distance, equality and decision making process. This paper also touches upon certain dark aspects of leadership. The method of collecting data constitutes of primary and secondary research. Primary research has been done by the way of unstructured face to face interview, telephonic interview and interview through emails, while secondary research includes books, journals, articles, magazines and online blogs.
\end{abstract}

Keywords-Leadership, Leadership Styles, Servant Leadership, HR Leadership, Consensual Decision Making, All Pervasive, Collaborator, Problem Solver, Architect

\begin{abstract}
Abstrak
Kepemimpinan adalah seni memotivasi sekelompok orang untuk bertindak untuk mencapai tujuan tertentu. Gaya kepemimpinan adalah metode dan pendekatan dalam memberikan arahan, melaksanakan rencana, dan memotivasi orang. Ini adalah jumlah total tindakan eksplisit dan implisit yang dilakukan oleh pemimpin. Studi ini menyelidiki gaya kepemimpinan yang berbeda dalam organisasi dan klasifikasi berdasarkan negara tentang bagaimana gaya kepemimpinan bervariasi di berbagai negara. Ini berdasarkan faktor-faktor seperti jarak kekuasaan, kesetaraan, dan proses pengambilan keputusan. Makalah ini juga menyinggung aspek gelap tertentu dari kepemimpinan. Metode pengumpulan data merupakan penelitian primer dan sekunder. Penelitian primer dilakukan dengan cara wawancara tatap muka tidak terstruktur, wawancara melalui telepon dan wawancara melalui email, sedangkan penelitian sekunder meliputi buku, jurnal, artikel, majalah dan blog online.
\end{abstract}

Kata kunci- Kepemimpinan, Gaya Kepemimpinan, Kepemimpinan SDM Kolaborator, Pemecah Masalah, Arsitek

\section{INTRODUCTION}

Leadership is a practice by which a person can express, direct and influence the behaviour and work of others towards achievement of precise goals in a given situation. It is the skill of a manager to persuade the subordinates to work with assurance and enthusiasm. It is an all-pervasive function. It is instrumental for every organisation whether be it corporate, academic, sports, politics or fashion industry to have a leader. A leader paves the way for his/her followers. The followers follow the footsteps of their leader. The leaders are the enablers for organisational effectiveness in the long run.We can say that a leader exhibits different leadership styles in the organisation. A new approach of leadership called the servant leadership is getting popular these days which stresses on serving people first then thinking about business later. This style of leadership replaces the self -interest with service to others. This paper also brings into account several dark tendencies of leadership which are related to their behavioural characteristics. 


\section{HYPOTHESIS DEVELOPMENT}

\section{A. Emerging Styles of Leadership}

Bill Taylor, in his article "The 4 Leadership Styles, and How to Identify Yours" has classified the 4 emerging leadership styles which are as follows The Classic Entrepreneur, John Doerr describes this type of leadership style as "more than anyone thinks possible with less than anyone thinks possible." This type of leaders cares about the values their company stands for but is more interested in getting ROI. Such types of leaders are conscious about the economic value and KPIs. They love to create good products and steer their company to new heights but when it comes to making important decisions about mergers and acquisitions, or selling a company they back their decision by thorough financial calculations. These leaders being old school tend to make cautious moves and every action they take is backed by suitable justification to the question "How do we benefit from this move?" (Taylor, 2016).

The Modern Missionary, such kind of leaders look into the social aspect of life. They view competition as a process of creating something unique and beautiful out of it rather than winning over the competitors. These leaders are passionate about human values and such values hold precedence over economic and financial outcomes. This style of leadership is heavily influenced by philanthropy. Leaders here give more emphasis on the impact they are making in the society and might even let go of certain projects which does not resonate with the company values in spite of being lucrative in nature. Such kind of leaders establishes a company with a cause. They have traits of servant leadership in themselves. (Taylor, 2016). The Problem Solver, such leaders focus more on the end goal rather than the cause. They believe in the power of expertise and experience. They are the first ones to identify new opportunities and brainstorm new ideas to confront difficulties. These leaders are more realistic and they tend to discuss the problems with their colleagues, superiors and also rely on their judgement and expertise. They are good forecasters and they aim to rebuild the organization using modern technology in order to establish them in the industry. (Taylor, 2016).

The Solution Finder, these leaders are the "hidden gems" of the organisation. They are the humblest people in the organisation. They always take help from their colleagues and consider their advice instrumental in reaching the goals of the organisation. Such leaders believe that everyone in the organisation is collectively responsible for the fulfilment of the organisation's goals and objectives. These leaders bring the spirit of "we" and "us" in the organization. They are good motivators and they tend to align the individual goals of the employees with the goals of the organization. They influence people around them to be ambitious and down to earth. (Taylor, 2016).

Alex Hill, Liz Mellon, Ben Laker and Jules Goddard in their article "The One Type of Leader Who Can Turn Around a Failing School" have classified the 5 types of leaders as follows: The Surgeons (cut and redirect):- These leaders are the problem identifiers and solvers. They quickly identify what's wrong and redirect all the resources to fixing the immediate problem. They believe that an organisation fails when the employees are not performing well. If they remove the poor performers and make the others work hard, the performance of the organisation will improve. They have a strong mind and follow discipline. They think that it is their responsibility to bring the organisation back in track with new rules and hard work. They invest more in senior employees due to their experience in the organisation, fire the poor performers, cut out the non-essential activities and trim the organisational hierarchy. These moves are taken by them in order to address the most pressing issue. Surgeon leaders are decisive and incisive. (Hill Alex.et.al, 2016).

The Soldiers (trim and tighten), these leaders love discipline and order. They hate wastage of any kind and focus on costs and deadlines. They are persistent, cost-cutting and task-focused leaders. As a cost-cutting measure, they cut down all the non-essential and support activities, introduce automation and start using cheaper supplies. Such leaders have a high profile inside the organisation but are hardly known outside as they fail to create an impact in the organisation. Soldier leaders create an environment of fear and uncertainty which de-motivate the employees. Their severe cost cutting measures helps to enhance the financial performance but delay in investments is detrimental to the health of the organisation in the long run. (Hill Alex.et.al, 2016). : The Accountants (invest and grow):- These leaders believe in numbers and think "If we're bigger, we'll be stronger". They seek ways to enhance revenue and make the organisation bigger and better. Such leaders are resourceful, systematic and opportunists. They look for ways in which the organization can tap new resources, acquire enterprises, invest in new ventures, and improve the existing organizational facilities with the view of intensifying the long term organizational performance. Accountant leaders bring a significant improvement in the revenue of the organization. (Hill Alex.et.al, 2016).

The Philosophers (debate and discuss):- These leaders are passionate about teaching and debating. They believe that an organisation fails because it is not teaching its employees properly. They consider themselves as experienced teachers rather than leaders. They are great observers and they take a deep interest in the interests, 
activities, performance of the employees. These leaders are slow and often consider organisational improvement as a time consuming and transformational process. (Hill Alex.et.al, 2016). The Architects (redesign and transform): - They are the transformational leaders who quietly redesign the organisation and create a positive impact in the community that it serves. They are those leaders who "get things done rather than sit around drinking coffee. They are intuitive, humble and visionary leaders who believe that an organisation fails as it's poorly designed. Therefore, such leaders set out to redesign the organisation and create the right environment for the employees at all levels. These leaders forecast future opportunities, bring about a positive change in the employee behaviour, enhance revenue and improve coaching and leadership within the organisation. Being great visionaries, such leaders take a 360-degree view of the organisation, its stakeholders, the customers, the competitors, the suppliers, the government, and the society as a whole. With their work, they leave behind a legacy for the future generations to follow. (Hill Alex.et.al, 2016). Tomas Chamorro-Premuzic and Michael Sanger's article "What Leadership Looks Like in Different Cultures" (HBR: May 6, 2016) talks about the classification of leaders on the basis of decision making and communication style. (Maner, 2016)

\section{B. On the basis of Decision Making}

A synchronized leader accurately integrates organization, project and people. They draw the organizational plans in the form of different projects and assign these projects to the people. Constant follow up is the most essential feature of this type of leadership style. These leaders also seek for consensus from the people to arrive at a common decision. Synchronized leaders tend to be more cautious and are more focused on potential threats than rewards. (Maner, 2016). This type of leader is more prevalent in regions like Northeast Asia (e.g., Mainland China, South Korea, and Japan), Indonesia, Thailand, the UAE, and much of Latin America (Mexico, Brazil, Colombia, Chile). (Maner, 2016).

An opportunist leader self-initiates and demonstrates elasticity on the ways to achieve the goal in order to be more liked by the people. They are motivated risk takers and tend to squeeze every opportunity that comes in the way. They are good listeners and they fully comprehend the power of listening to his or her people. They are good examples of servant leaders. They are less concerned about the spotlight and they find joy in serving people. Such leaders understand the value of relationships and consider them as the building blocks of an organization. They are willing risk takers and they look forward to leaving their mark on the world and add value to others on the way. (Maner, 2016). This type of leader is found in Germanic and Nordic Europe (Germany, the Netherlands, Denmark, Norway), the UK, Western countries on which the UK had substantial cultural influence (the U.S., Australia, and New Zealand), and Asian countries that based their governing and economic institutions on the British model (India, Singapore, Malaysia, Hong Kong).(Maner, 2016)

\section{On the basis of Communication Style}

Straight-Shooting Leader, this type of leader is honest and open in his business dealings. They are very transparent while communicating to their subordinates. They clearly spell out what is expected from the subordinates and measure their performance as per the stated standards and make them aware of the deviations in their performance. Impromptu performance review meetings help such leaders to understand the work of the subordinates better. Such leaders are honest and they possess integrity which is very valuable in business, as people may be more willing to do business with someone they perceive as trustworthy. This type of leadership is found in Northeast Asia and countries like the Netherlands. (Maner, 2016).

Diplomatic Leader, this type of leadership style comprises of leaders with good communication skill and they know the art of careful communication in order to get along well with people. They are polite and agreeable and tend to keep conversations pleasant. Diplomatic leadership involves negotiating, representing interests and policies, speaking publicly and resolving conflicts. (Maner, 2016). In places like New Zealand, Sweden, Canada, and much of Latin America, this type of leadership style prevails. (Maner, 2016)

\section{Servant Leadership}

Servant leadership is a tried and tested leadership style which focuses on creating a shift from managing for results to designing environment to create results. (Greenleaf, 1977). Robert Greenleaf first coined the phrase "Servant leadership" in the 1970s. It is a form of leadership which replaces the self -interest with service to others.. Servant leaders demonstrate a range of 9 key attributes - listening, self-awareness, foresight, empathy, persuasion, stewardship, healing, conceptualisation and community. Servant leadership is about transformation and future focus and adopting its leadership principles compliments responsive ways of working really well. Due to this the nature of working in the workplace has changed drastically. Our leaders need to change in order to maximize delivery in customer value and to adapt to new circumstances. According to Economist Intelligence Unit, the top 3 emerging requirements are ability to motivate, ability to work well across cultures and geographical boundaries, and ability to facilitate change (Agile, 2016). 


\section{E. The Dark side of leadership}

Passive- aggressive leaders are cynical individuals who find faults in everything and procrastinate the work given to them. They are the 'resisters' of the group and are purposely unproductive. There are two reasons behind their resistance- fear of failure and fear of success. They fear that success could raise the bar of expectations from the superiors which could eventually lead to the fear of failure. Passive-aggressive leaders are always bitter and critical. Their aversion to conflict creates a great deal of conflict. (Maner, 2016) Such leaders enjoy the perks of the leadership position but fear any kind of responsibility. They consider "others" responsible for failure and themselves attributable to success. Due to the constant battle with their inner selves, there is often an outburst of emotions in the form of anger and frustration. When things do not go as per their desires, they tend to be verbally abusive and act in manners which are not socially and professionally acceptable. (Maner, 2016).

Randall S. Peterson and S. Wiley Wakeman in their article "The Type of Narcissist That Can Make a Good Leader" talks about Narcissist leadership is a leadership style where the leader is only interested in him. They prioritize themselves at the cost of others. Arrogance, authority and aggression are the principle characteristics of this leadership style. Narcissism is described as unhealthy and destructive. It is fuelled by the love for power and admiration. (Peterson.et.al, 2017). A study published in the journal 'Personality and Social Psychology Bulletin' suggests that narcissist leaders usually take charge of a leaderless group. Narcissist leaders are a big mystery for the organization. On one hand they are charismatic leaders having an impressive vision for the organization. On the other hand, they tend to flare up when their expertise is min accurately explained. "I", "me" and "myself" are the 3 most important words for a narcissist leader. They have to face many challenges like- stubborn conflict, high staff turnover due to the inability to sympathize and share credit, debate and confusion due to the reluctance to explain themselves to others. Narcissist leaders are valuable when change is being introduced but trouble otherwise. (Peterson.et.al, 2017).

Researchers have studied three main characteristics of incompetent leaders. They can be classified as:-

1. "moving away behaviour"- which creates distance from others through hyper- emotionality, diminished communication, and disbelief that erodes trust

2. "moving against behaviour" - which overshadow and influence people while ennobling the self;

3. "moving toward behaviour"- which include being sycophantic, overly compliant, and hesitant to take chances or stand up for one's team. (Gregory,2018)

Absentee leaders are the silent killers of the organization. No action is taken against such leaders because the organisation always has some other leader whose behaviour is more deviant. The negative impact created by absentee leaders is hard to detect and the symptoms of damage take a long time to appear.

\section{F. Leadership practices across select countries}

Leadership style in Japan- hierarchical (more attention given to the rank and status of the person), a mixture of hierarchical leadership style with consensual decision making, "nemawashi"- the practice of speaking with each individual stakeholder before a meeting in order to shape the group decision and develop agreement in advance, "ringi" - which involves passing a proposal around level by level, starting at the bottom and then working through the layers of middle and senior management before arriving at the top. (Meyer 2017).

Leadership style in America-egalitarian (equality for all), biggest leadership trend in Western Europe and USA has been abandoning the hierarchical leadership style for a more egalitarian style of leadership, the egalitarian leadership style replaces command and control with empowerment, MBO, 360-degree feedback, open door policies, flat organizational structure are some key features of this style of leadership, creativity and innovation are the end products of such a leadership style, americans believe in quick decision making, so the decision making power is usually vested in the boss. The boss may consult his team in the decision making process but the final decision is taken by him. (top down approach or small $\mathrm{d}$ of decision making) (Emmerick 2008).

Leadership style in China - In China the egalitarian leadership style is a major flop as the employees depend upon their managers for orders or commands. They just tend to follow instruction of their superiors. They perceive their managers to be arrogant when they are given the freedom to take independent decisions. (Emmerick 2008) Leadership style in India, Mexico, Morocco and Russia -Here the leader follows a top down approach while making decisions. The decisions are made quickly but they are subject to change as new ideas or inputs emerge. 
The decision is not the firm commitment but subject to change depending upon the circumstances.(Emmerick 2008). Leadership style in Germany, Japan, the Netherlands, and Sweden -The decision making is consensual (Big D). Here a lot of people are involved in the decision making process and it involves a lot of negotiation to reach a common ground. However, once the decision is made, implementation is surprisingly quick. (Largest car manufacturers in the world) (Meyer 2017). Leadership style in France, Finland and Argentina- The leadership is autocratic, directive and non-participative in nature. (Emmerick 2008).

\section{CONCLUSION}

On the successful completion of this research paper, I have been able to identify a lot of emerging leadership styles. The leadership styles also vary across nations. It was seen that the countries in the Eastern hemisphere follow a hierarchical leadership style whereas the western nations follow a more egalitarian leadership style. The western nations follow a series of initiatives like open door policies, 360-degree feedback mechanism, flat organization structure to name a few which are typical characteristics of an egalitarian leadership style. On the other hand, the eastern nations follow a top down, hierarchical leadership style where power and authority play pivotal roles in shaping up this leadership style.

The style of leadership also varies greatly from organisation to organisation. All the interviewed leaders considered the leader as the pivot of their team. Creating a culture for the empowerment of the youth is important for the leaders.

\section{REFERENCES}

Alafeshat R and Tanova C (2019): "Servant Leadership Style and High- Performance Work System Practices: Pathway to a Sustainable Jordanian Airline Industry", MDPI Journal

Ataya R (December 2019): "How I Did It" : The CEO of Bayt.com on Building an Internet Culture Where There Is No Internet

Berinato S(2008): Sustainability, Tokyo's “Just Do It” Leadership on Climate Change, Harvard Business Review Buckingham M (2005) :’What Great Managers Do", Harvard Business Review

Di Fabio A and María Peiró J (2018): "Human Capital Sustainability Leadership to Promote Sustainable Development and Healthy Organizations" : A New Scale, MDPI Journal

Doan M (2019): “Companies Need to Rethink What Cybersecurity Leadership Is" , Harvard Business Review

DuVernay C (2006): “Avoid Mistakes That Plague New Leaders” - An Interview with Warren Bennis, Harvard Business Review

Emmerik H, Leuven M, Wendt H Group (2008): "Leadership Behaviors around the World The Relative Importance of Gender versus Cultural Background”, International Journal of Cross Cultural Management, IJ.

Goleman D (2013): “The Focused Leader How effective executives direct their own — and their organizations'attention", Harvard Business Review

Gregory S (2018): The Most Common Type of Incompetent Leader, Harvard Business Review

Greenleaf R (1977): Servant Leadership- A Journey into the Nature of Legitimate Power and Greatness, 338pg, published by Paulist Press

Hill A, Mellon L, Laker B and Goddard J (2016) :"The One Type of Leader Who Can Turn Around a Failing School", Harvard Business Review

Ibarra H and Scoular A (2019): “The Leader as Coach”, Harvard Business Review Ignatius A (2019): Leadership Transitions - "Starbucks CEO Kevin Johnson on Work, Joy, and Yes, Coffee", Harvard Business Review

Ignatius A (2019): Article Leadership Transitions Starbucks CEO Kevin Johnson on Work, Joy, and, Yes, Coffee, Harvard Business Review

Lundberg A and Westerman G(2020): “The Transformer CLO”, Harvard Business Review

Mahwah, Erlbaum L (2007): Book Review : J.S. Chhokar, F.C. Brodbeck and R.J. House (eds), Culture and Leadership around the World: The GLOBE Book of In-depth Studies of 25 Societies., SAGE Publications , $\mathrm{CCM}$ 
Maner J (2016): “Good Bosses Switch Between Two Leadership Styles”, Harvard Business Review Meyer E (2017): Leading Teams, Being the Boss in Brussels, Boston, and Beijing, Harvard Business Review Naskar, P., Ray Chaudhuri, M. and Sur, S. (2013) "The Quintessence of Leadership Behavior in the Corporate Hemisphere: Magnitude, Environment, Quality, Crises and Organizational Transformation”, in IJMDS Vol. 1, No. 1 Chennai

Northouse P (2012): Leadership- Servant Leadership, SAGE Journal South Asia Edition, Vol 5

Peterson R and Wakeman S (2017): “The Type of Narcissist That Can Make a Good Leader", Harvard Business Review

Premuzic T and Sanger M (2016): "What Leadership Looks Like in Different Cultures”, Harvard Business Review Rao R (2019): "HR Leadership and Millennial Employees”, Corporate Citizens Magazine, Vol 5, Issue No1

Ray Chaudhuri, M., Kettunen J. and Naskar, P. (2015) "Transformational and Servant Leadership: Evidence from Indian Higher Education" in The Online Journal of Quality in Higher Education (TOJQIH) Vol. 2, Issue 4 from Sakarya University, Sakarya, Turkey

Ray Chaudhuri, M., Kettunen, J. and Naskar, P. (2015) "Reflections from Leadership Styles from Higher Education in India", in Universal Journal of Management (UJM), Vol. 3, No. 10, Horizon Research Publishing Corporation, California, USA. Enlisted in Social Science Research Network [SSRN], Rochester, New York, USA

Ray Chaudhuri, M., Naskar, P. and Sur, S. (2015) "Holding the Twines of Organizational Rejuvenation: Emphasizing the Human Factor" in Contemporary Issues in Sustaining Business in Emerging Global Markets edited by Singh et al, School of Management, Vivekananda Institute of Professional Studies, Guru Govind Singh Indraprastha University, New Delhi, published by Excel Books, New Delhi

Ray Chaudhuri M., Naskar, P. and Sur, S. (2013) "Strategising a Face-Lift for Workplace Dexterity in Organizations: Examining Dimensions, Perspectives, Promises and Relations", in the conference proceedings of National HR Conference on 'Developing People Strategy for Global Competitiveness' from Xavier Institute of Social Service (XISS), Ranchi

Smith W, Lewis M, and Tushman M (2016): "Both/And” Leadership, Harvard Business Review

Taylor B (2016): “The 4 Leadership Styles, and How to Identify Yours”, Harvard Business Rview 